\title{
Nonlinear Programming for Solvent Extraction of Jatropha Curcas Seed Oil for Biodesiel Production
}

\author{
O. O. Ogunleye ${ }^{1, *}$, O. A. A. Eletta ${ }^{2}$ \\ ${ }^{1}$ Department of Chemical Engineering, Ladoke Akintola University of Technology, P.M.B. 4000, Ogbomoso, Nigeria \\ ${ }^{2}$ Department of Chemical Engineering, University of Ilorin, P.M.B. 1515, Ilorin, Nigeria
}

\begin{abstract}
Nonlinear programming models of solvent extraction of Jatropha curcas oil that forms the thrust of this paper is uncommon in literature. The oil was extracted using two solvents (n-hexane and Isopropanol) at a powder weight to solvent volume of $1: 5$ and particle size of between $0.5 \mathrm{~mm}$ and $0.75 \mathrm{~mm}$. A randomized 31 set of central composite design comprising three factors (solvent composition $\left[0-100 \% \mathrm{n}\right.$-haxane], time of extraction $[1-5$ hours $]$ and extraction temperatures $\left[40-60^{\circ} \mathrm{C}\right.$ ) at five levels were experimented. Oil yield, specific gravity, viscosity, free fatty acid (FFAs) and iodine value of the oil extracts were determined. Response equation of each of oil yield $\left(\mathrm{R}_{1}\right)$, specific gravity $\left(\mathrm{R}_{2}\right)$, viscosity $\left(\mathrm{R}_{3}\right)$, FFA $\left(\mathrm{R}_{4}\right)$ and iodine value $\left(\mathrm{R}_{5}\right)$ in terms of solvent composition $\left(\mathrm{X}_{1}\right)$, time of extraction $\left(\mathrm{X}_{2}\right)$ and temperature $\left(\mathrm{X}_{3}\right)$ were developed. These were formulated into a nonlinear programme that maximize oil yield and minimizes other four properties according to ASTM D6751-07b and EN 14214-2008 (E) standards for biodiesel production. The coefficients of determination $\left(\mathrm{R}^{2}\right)$ for the responses equations were $1.000,1.000,0.953,0.963$ and 0.968 respectively. The nonlinear programme yields a maximum oil yield $\left(\mathrm{R}_{1}\right)$ of $37.3507 \%, \mathrm{R}_{2}=0.88597, \mathrm{R}_{3}=39.771, \mathrm{R}_{4}=2.1185$ and $\mathrm{R}_{5}=101.51$, while the optimum operating conditions were $\mathrm{X}_{1}=2(100 \% \mathrm{n}$ haxane $), \mathrm{X}_{2}=2(5$ hours $)$ and $\mathrm{X}_{3}=2\left(60^{\circ} \mathrm{C}\right)$. This study has clearly demonstrated the applicability of nonlinear mathematical programming in selecting extraction conditions for jatropha oil from its seed.
\end{abstract}

Keywords Jatropha Oil, Oil Yield, Nonlinear, Biodiesel, Optimum

\section{Introduction}

Jatropha curcas belongs to a very large family, Euphorbiaceae. It has numerous common names depending on the country where it is found, but is most commonly referred to as physic nut or purging nut[1]. Jatropha curcas is known in Nigeria by various local names as "butuje", "lapapa", "ologbo"[2]. The seeds of Jatropha contain viscous oil, which can be used for the manufacture of candles and soap, in the cosmetics industry, as a diesel/paraffin substitute or extender that is a practical substitute for fossil fuels to counter greenhouse gas accumulation in the atmosphere[3]. It has a yield per hectare of more than four times that of soya beans and 10 times that of corn[4]

Jatropha oil belongs to the family of vegetable oils that are now promising alternatives in solving energy

problems due to several advantages; it is renewable, environ-friendly and can be produced easily in rural areas, where there is an acute need for modern forms of energy[5]. Many of these oils, including palm oil, soybean oil, sunflower oil, rapeseed oil, and canola oil have been used to produce biodiesel fuel and lubricants[5]. The fact that Jatro-

* Corresponding author:

ooogunleye@yahoo.com (O. O. Ogunleye)

Published online at http://journal.sapub.org/ijee

Copyright (C) 2012 Scientific \& Academic Publishing. All Rights Reserved pha oil cannot be used for nutritional purposes without detoxification makes its use as fuel source very attractive.

Several methods can be used to obtain vegetable oil from the seeds; this include, mechanical pressing, supercritical fluid extraction, and solvent extraction[6]. Mechanical extraction is the most widely used method of extraction. However, the oil produced with this method is turbid, contains a significant amount of water, and metals contents, which makes them less suitable for biodiesel production[7]. In extraction using supercritical fluid, the oil produced has very high purity; however, the operating and investment cost is high. Extraction using solvent has several advantages, which includes; higher yield and less turbid oil than mechanical extraction, and relative low operating cost compared with supercritical fluid extraction.

The use of vegetable oil in producing fuel is limited to diesel engine because they contain free fatty acids (FFAs), phospholipids, sterols and other impurities[7]. They have very high viscosity which is about 17 times higher than that of the fossil fuel and can affect spray atomization, vapourization and air -fuel mixing in the combustion chambers, leading to an adverse effect on the combustion chamber[8]. Production of biodiesel from Jatropha oil has been studied by several researchers with different production processes and conditions[9-15].

Biodiesel is a fuel obtained from renewable biomass feedstock (It is renewable, non-toxic and biodegradable) 
which consists of mono alkyl esters usually produced by transeterification of vegetable oils, fat and cooking oil using low molecular weight alcohols. Commonly used alcohols are methanol and ethanol[16]. Transesterification can be carried out with or without a catalyst and using a base or acid catalyst. Studies have reported greater yield using an acid catalyst. When $\mathrm{NaOH}$ was used, at the optimized conditions, biodiesel yield was only $47.2 \%$ and soap foams were formed when product was dropped in distilled water, which solidifies to soap like material within 2 hours in a saponification reaction between $\mathrm{NaOH}$ and FFA. Transesterification of Jatropha oil using super critical methanol in the absence of catalyst has been studied[17]. With $\mathrm{H}_{2} \mathrm{SO}_{4}$ as catalyst, and at a longer reaction time, biodiesel yield was increased to $92.8 \%$. FFA in bio diesel can be reduced using a two-step approach with potassium hydroxide as a catalyst[18].

The crux of the transesterification for biodiesel production remains that of FFA, moisture contents, viscosity, iodine value and saponification value of the Jatropha oil feedstock. High FFA above 1\% w/w yields low biodiesel production but favours the production of soap. This low FFA is achieved through mechanical extraction but fails the moisture content requirement that is more critical. High viscosity and iodine value of Jatropha oil are not desirable for biodiesel production for operational reasons like carbon deposits and oil ring sticking[5]. However, the yield of extractable oil from Jatropha and its properties have been said to depend on the composition of the extract solvent, the temperature and the time of heating[19-20].

In this study, solvent extraction of oil from Jatropha seed was studied to investigate the effects of process parameter such as temperature, time and solvent composition on the yield and quality of the extract. This also led to the formation and solution of nonlinear programming model for maximizing oil yield subject to biodiesel feedstock requirements.

\section{Materials and Method}

\subsection{Materials Preparation}

Jatropha curcas seed used in this study were obtained from Ogbomoso, Nigeria. The seed had moisture content of $6.20 \%$ and oil content of $40.0 \%[21]$. The seeds were repeatedly washed to remove dirts and other impurities. It was subsequently dried in oven at $50^{\circ} \mathrm{C}$ until it reached constant moisture content. These seeds were grounded and sieved to get particle size of between $0.5 \mathrm{~mm}$ and $0.75 \mathrm{~mm}$.

\subsection{Oil Extraction}

Jatropha curcas seed oil was extracted using two solvents (n-hexane and Isopropanol). Jatropha seed powder weight (g) to solvent volume (ml) of 1:5 was adopted[6]. These extractions involved three factors (solvent composition, time of extraction and extraction temperature) at five levels as presented in the experimental design. At the set time interval, the samples were taken and centrifuged to separate the solid fraction from the solution. The extracts were heated and evaporated using rotary evaporator apparatus to obtain solvent-free oils.

\subsection{Determination of Oil Properties}

The oil yield, specific gravity, viscosity, free fatty acid and iodine value were determined. Parameters were determined in triplicates and the mean taken for grater accuracy.

(i) Oil Yield (\%): The weight of oil extracted from $20 \mathrm{~g}$ of seed powder was determined and expressed as the percentage of oil in the dry matter of seed powders.

(ii) Specific Gravity: The specific gravity of the samples was determined at $25^{\circ} \mathrm{C}$.

(iii) Viscosity (centipoises): Viscosity of seed oil was carried out using rotational viscometer at $10 \mathrm{rpm}$ at a temperature $25^{\circ} \mathrm{C}$.

(iv) Free Fatty Acid (FFA), (\%): Acid value of seed oil was determined according to AOAC Official Method Cd 3a63. Percentage free fatty acids (FFAs) were calculated using oleic acid as a factor.

(v) Iodine value (g iodine $/ \mathbf{1 0 0} \mathrm{g}$ ): Iodine value of seed oil was determined according to AOAC Official Method 993.20.

\subsection{Experimental design}

The design was based on the fact that oil yields and physical properties are functionally related to the three factors (solvent composition, time of extraction and extraction temperature)[22]. A centre point for the design was selected with ingredients at levels expected to yield, at least, satisfactory experimental results. The list of the factors for centre point is as shown on Table 1.

Table 1. Extraction Factors at the Design Centre Point

\begin{tabular}{ccc}
\hline Factors & Symbol & Centre point \\
\hline Solvent $(\%)$ & $\mathrm{x}_{1}$ & 50 \\
Time (hours) & $\mathrm{x}_{2}$ & 3 \\
Temperature $\left({ }^{\circ} \mathrm{C}\right)$ & $\mathrm{x}_{3}$ & 50 \\
\hline
\end{tabular}

The design was based upon the symmetrical selection of variation increments about the centre point and the level of variation were chosen to be within the boundary range of the factors. The increment of the variation for each variable spaced around the centre point ratios are presented in Table 2.

Table 2. Experimental Increments, values of coded levels

\begin{tabular}{ccccccc}
\hline \multicolumn{7}{c}{$\mathrm{X}_{\mathrm{i}}$ Coded Levels } \\
\hline Factors & $\begin{array}{c} \pm \text { Incre- } \\
\text { ment }\end{array}$ & -2 & -1 & 0 & +1 & +2 \\
\hline $\mathrm{x}_{1}$ & \pm 25.00 & 0.00 & 25.00 & 50.00 & 75.00 & 100.00 \\
$\mathrm{x}_{2}$ & \pm 1.00 & 1.00 & 2.00 & 3.00 & 4.00 & 5.00 \\
$\mathrm{x}_{3}$ & \pm 15.00 & 40.00 & 45.00 & 50.00 & 55.00 & 60.00 \\
\hline
\end{tabular}

where the $x_{i}$ and the coded $X_{i}$ ratios are related by the following equations:

$$
X_{1}=\frac{\left(x_{1}-50\right)}{25}
$$




$$
\begin{gathered}
X_{2}=\frac{\left(x_{2}-3\right)}{1} \\
X_{3}=\frac{\left(x_{3}-50\right)}{5}
\end{gathered}
$$

By substituting these equations, compositions were coded for solution of the multiple regression equation.

\subsection{Response Equations}

As pointed out by[23] and[24], regression analysis provides a conceptually simple method for investigating functional relationships among variables. Regression models were formulated for each of the five properties of oil as a function of the three process factors. SPSS version 11.0 package was used for this analysis. In multiple regression as in the present case, $R^{2}$, which is the square of the adjusted coefficient of determination and standard error are the indices. $F$ statistics shows the significance of the overall model while the $t$ statistics tests the significance of each of the variables of the model. The function was assumed to be approximated by a second degree polynomial equation :

$$
R_{k}=b_{k 0}+\sum_{i=1}^{3} b_{k i} X_{i}+\sum_{i=1}^{3} b_{k i i} X_{i}^{2}+\sum_{i \neq j=1}^{3} b_{k i j} X_{i} X_{j}
$$

Where $\mathbf{R}_{\mathbf{1}}$ : Oil yield (\%), $\mathbf{R}_{\mathbf{2}}$ : Oil specific gravity, $\mathbf{R}_{\mathbf{3}}$ : Oil viscosity at room temperature (centipoises), $\mathbf{R}_{\mathbf{4}}$ : Free Fatty Acid as oleic acid (\%) and $\mathbf{R}_{\mathbf{5}}$ : Iodine value (g/g).

Maximization and minimization of the polynomial thus fitted was performed by numerical techniques, using the optimization toolbox of matlab 7.50 version of Mathworks Inc. The response surfaces and contour plots for these models were plotted as a function of two variables, while keeping the other one variable at the optimum level.

\subsection{Nonlinear Programme for Oil Yield}

A nonlinear programming problem of the form of equations 5 to 10 was formed from the vector of equation 4 as follows:

$$
\text { Maximize: } R_{1}\left(X_{i}\right)
$$

Subject to :

$$
R_{2}\left(X_{i}\right) \leq b_{2}
$$

$$
\begin{gathered}
R_{3}\left(X_{i}\right) \leq b_{3} \\
R_{4}\left(X_{i}\right) \leq b_{4} \\
R_{5}\left(X_{i}\right) \leq b_{5} \\
-2 \leq X_{i} \leq+2
\end{gathered}
$$

Where $\boldsymbol{b}_{\boldsymbol{i}}$ are the biodiesel feedstock requirements. This constrained maximization problem was solved using a routine of the optimization toolbox of matlab 7.50 version of Mathworks Inc.

\section{Results and Discussion}

\subsection{Response Equations}

The results of the fractional central composite design for evaluating the effects of solvent composition, time and temperature of extraction on the oil yield, density, viscosity, FFAs and Iodine values are presented in Table 3. This was subsequently used to fit the response equations for all the five oil properties. Table 4 shows the factors of the models, their parameter estimates and the statistics of the estimates for the best functions adopted, taking into consideration all main effects, linear, quadratic, and interaction for each model. Analyses were conducted to evaluate the adequacy and consistency of the models. The analysis of variance of the models is presented in Table 5. The analysis of variance calculated assessed how well the model represented the data. As shown on the Table 5, the F-value for the Oil yield is 10515043 that is significant at 95\% level implying good model fit. Similar significant values were also evaluated for specific gravity, viscosity, FFA and Iodine value on Table 5. The coefficients of determination $\left(\mathrm{R}^{2}\right)$ for the responses

\begin{tabular}{|c|c|c|c|c|c|c|c|c|c|c|}
\hline \multicolumn{11}{|c|}{ Estimated Coefficients } \\
\hline \multirow{2}{*}{ Factors } & \multicolumn{2}{|c|}{$\mathrm{R}_{1}$} & \multicolumn{2}{|c|}{$\mathrm{R}_{2}$} & \multicolumn{2}{|c|}{$\mathrm{R}_{3}$} & \multicolumn{2}{|c|}{$\mathrm{R}_{4}$} & \multicolumn{2}{|c|}{$\mathrm{R}_{5}$} \\
\hline & Coefficients & $\mathrm{p}$-value & Coefficients & $p$-value & Coefficients & $\mathrm{p}$-value & Coefficients & $\mathrm{p}$-value & Coefficients & $\mathrm{p}$-value \\
\hline Constant & 28.069 & 0.000 & 0.914 & $0.000 *$ & 40.182 & $0.000 *$ & 3.024 & $0.000^{*}$ & 105.809 & $0.000 *$ \\
\hline $\mathrm{x}_{1}$ & 1.650 & $0.000^{*}$ & $-5.057 \mathrm{E}-03$ & $0.000^{*}$ & -0.551 & $0.000^{*}$ & -0.293 & $0.000^{*}$ & -0.764 & $0.000 *$ \\
\hline $\mathrm{x}_{2}$ & 0.737 & $0.000^{*}$ & $-2.227 \mathrm{E}-03$ & $0.000^{*}$ & $-3.822 \mathrm{E}-02$ & 0.367 & $-6251 \mathrm{E}-03$ & 0.714 & -0.416 & $0.000 *$ \\
\hline $\mathrm{x}_{3}$ & 2.256 & $0.000^{*}$ & $-6.891 \mathrm{E}-03$ & $0.000 *$ & -0.211 & $0.000 *$ & $-9.090 \mathrm{E}-02$ & $0.000^{*}$ & -0.710 & $0.000 *$ \\
\hline $\mathrm{x}_{1}{ }^{2}$ & $2.702 \mathrm{E}-04$ & 0.430 & $3.052 \mathrm{E}-05$ & 0.480 & 0.198 & $0.000^{*}$ & $-1.887 \mathrm{E}-02$ & 0.146 & -0.129 & $0.018^{*}$ \\
\hline $\mathrm{x}_{2}{ }^{2}$ & $-1.078 \mathrm{E}-03$ & $0.009 *$ & $9.439 \mathrm{E}-06$ & 0.843 & $1.013 \mathrm{E}-02$ & 0.771 & $2.158 \mathrm{E}-02$ & 0.136 & $6.104 \mathrm{E}-04$ & 0.991 \\
\hline $\mathrm{x}_{3}{ }^{2}$ & $-3.218 \mathrm{E}-04$ & 0.312 & $7.784 \mathrm{E}-05$ & 0.060 & $-1.096 \mathrm{E}-02$ & 0.705 & $-8.788 \mathrm{E}-03$ & 0.456 & $6.249 \mathrm{E}-02$ & 0.193 \\
\hline $\mathrm{x}_{1} \mathrm{x}_{2}$ & $1.978 \mathrm{E}-04$ & 0.466 & $1.619 \mathrm{E}-05$ & 0.635 & $2.192 \mathrm{E}-03$ & 0.929 & $-2.137 \mathrm{E}-03$ & 0.831 & $-5.107 \mathrm{E}-02$ & 0.214 \\
\hline $\mathrm{x}_{1} \mathrm{x}_{3}$ & $-1.785 \mathrm{E}-05$ & 0.949 & $8.122 \mathrm{E}-05$ & $0.030 *$ & $8.028 \mathrm{E}-02$ & $0.005^{*}$ & $-3.443 \mathrm{E}-02$ & $0.003^{*}$ & $7.361 \mathrm{E}-02$ & 0.089 \\
\hline $\mathrm{x}_{2} \mathrm{x}_{3}$ & $1.657 \mathrm{E}-04$ & 0.543 & $8.122 \mathrm{E}-05$ & 0.575 & $4.564 \mathrm{E}-03$ & 0.855 & $-5.447 \mathrm{E}-03$ & 0.588 & $5.809 \mathrm{E}-02$ & 0.162 \\
\hline $\mathrm{R}^{2}$ & \multicolumn{2}{|c|}{1.000} & \multicolumn{2}{|c|}{1.000} & \multicolumn{2}{|c|}{0.953} & \multicolumn{2}{|c|}{0.974} & \multicolumn{2}{|c|}{0.968} \\
\hline
\end{tabular}
$(1.000,1.000,0.953,0.963$ and 0.968 respectively) are quite high for response surfaces, and indicated that the fitted quadratic models accounted for more than $96 \%$ of the variance in the experimental data, which were found to be highly significant. Based on t-statistics, the only regression coefficients significant at $95 \%$ were selected for inclusion in the equations (11) to (15).

Table 4. Estimated coefficients of the fitted quadratic equation for different responses

* The p-values in bold indicate the significance at $\mathrm{p}<0.05$ 
Table 3. Central composite design arrangement and responses

\begin{tabular}{|c|c|c|c|c|c|c|c|c|}
\hline \multirow{2}{*}{$\begin{array}{c}\text { Exp. } \\
\text { No }\end{array}$} & \multicolumn{3}{|c|}{ Factors at coded levels } & \multicolumn{5}{|c|}{ Responses } \\
\hline & $X_{1}$ & $\mathrm{X}_{2}$ & $\mathrm{X}_{3}$ & $\mathrm{R}_{1}$ & $\mathrm{R}_{2}$ & $\mathrm{R}_{3}$ & $\mathrm{R}_{4}$ & $\mathrm{R}_{5}$ \\
\hline 1 & -2 & -2 & -2 & 18.78 & 0.94 & 42.76 & 3.68 & 109.40 \\
\hline 2 & -2 & -2 & -1 & 21.04 & 0.93 & 42.70 & 3.60 & 108.34 \\
\hline 3 & -2 & -2 & 0 & 23.29 & 0.93 & 42.70 & 3.60 & 107.56 \\
\hline 4 & -2 & -2 & +1 & 25.55 & 0.92 & 41.40 & 3.53 & 106.78 \\
\hline 5 & -2 & -2 & +2 & 27.8 & 0.91 & 41.40 & 3.52 & 105.99 \\
\hline 6 & -2 & 0 & 0 & 24.77 & 0.92 & 42.40 & 3.52 & 107.05 \\
\hline 7 & -2 & +2 & +2 & 30.75 & 0.91 & 41.30 & 3.52 & 104.97 \\
\hline 8 & -1 & -1 & -1 & 23.42 & 0.93 & 41.20 & 3.48 & 107.51 \\
\hline 9 & -1 & -1 & +2 & 30.19 & 0.91 & 40.30 & 3.36 & 105.16 \\
\hline 10 & -1 & 0 & 0 & 26.42 & 0.92 & 40.50 & 3.40 & 106.47 \\
\hline 11 & -1 & +2 & +2 & 32.40 & 0.90 & 40.10 & 3.20 & 104.39 \\
\hline 12 & 0 & -2 & 0 & 26.59 & 0.92 & 40.20 & 3.02 & 106.41 \\
\hline 13 & 0 & 0 & 0 & 28.07 & 0.91 & 39.90 & 2.96 & 105.90 \\
\hline 14 & 0 & 0 & -2 & 23.56 & 0.93 & 40.30 & 3.02 & 107.47 \\
\hline 15 & 0 & 0 & +2 & 32.58 & 0.90 & 39.90 & 2.78 & 104.33 \\
\hline 16 & 0 & +2 & +2 & 34.05 & 0.90 & 39.80 & 2.72 & 103.82 \\
\hline 17 & +1 & -2 & -2 & 23.73 & 0.93 & 40.30 & 2.98 & 107.41 \\
\hline 18 & +1 & -1 & -1 & 26.72 & 0.92 & 40.30 & 2.90 & 106.37 \\
\hline 19 & +1 & -1 & +1 & 31.24 & 0.90 & 39.90 & 2.72 & 104.80 \\
\hline 20 & +1 & +1 & -2 & 25.94 & 0.92 & 40.30 & 2.92 & 106.64 \\
\hline 21 & +1 & +1 & 0 & 30.46 & 0.91 & 39.86 & 2.74 & 105.07 \\
\hline 22 & +1 & +2 & +2 & 35.70 & 0.89 & 39.78 & 2.62 & 103.25 \\
\hline 23 & +2 & -2 & -2 & 25.38 & 0.92 & 39.90 & 2.80 & 106.83 \\
\hline 24 & +2 & -2 & +2 & 34.40 & 0.89 & 39.80 & 2.12 & 103.70 \\
\hline 25 & +2 & -1 & +2 & 35.14 & 0.89 & 39.76 & 2.08 & 103.44 \\
\hline 26 & +2 & 0 & 0 & 31.37 & 0.90 & 39.80 & 2.19 & 102.78 \\
\hline 27 & +2 & 0 & +2 & 35.88 & 0.89 & 39.74 & 2.01 & 102.68 \\
\hline 28 & +2 & +1 & +2 & 36.62 & 0.89 & 39.72 & 1.98 & 102.62 \\
\hline 29 & +2 & +2 & +2 & 37.35 & 0.89 & 39.5 & 1.96 & 102.57 \\
\hline 30 & +2 & +2 & -2 & 28.33 & 0.91 & 39.88 & 2.76 & 103.20 \\
\hline 31 & +2 & +2 & 0 & 32.84 & 0.90 & 39.76 & 2.56 & 102.74 \\
\hline
\end{tabular}

Table 5. Analysis of variance for different models

\begin{tabular}{|c|c|c|c|c|c|}
\hline Responses & Sources of Variation & D.F & Sum of squares & Mean square & $\mathrm{F}$ \\
\hline \multirow{3}{*}{$\mathrm{R}_{1}$} & Regression & 9 & 730.277 & 81.142 & $10515043 *$ \\
\hline & Residual & 21 & $1.621 \mathrm{E}-04$ & 7.717 E-06 & \\
\hline & Total & 30 & 730.278 & & \\
\hline \multirow{3}{*}{$\mathrm{R}_{2}$} & Regression & 9 & $6.716 \mathrm{E}-03$ & $7.462 \mathrm{E}-04$ & $6060.893 *$ \\
\hline & Residual & 21 & $2.586 \mathrm{E}-06$ & $1.231 \mathrm{E}-07$ & \\
\hline & Total & 30 & $6.719 \mathrm{E}-03$ & & \\
\hline \multirow{3}{*}{$\mathrm{R}_{3}$} & Regression & 9 & 27.728 & 3.081 & $47.229 *$ \\
\hline & Residual & 21 & 1.370 & $6.523 \mathrm{E}-02$ & \\
\hline & Total & 30 & 29.097 & & \\
\hline \multirow{3}{*}{$\mathrm{R}_{4}$} & Regression & 9 & 8.473 & 0.941 & $88.020 *$ \\
\hline & Residual & 21 & 0.225 & $1.070 \mathrm{E}-02$ & \\
\hline & Total & 30 & 8.697 & & \\
\hline \multirow{3}{*}{$\mathrm{R}_{5}$} & Regression & 9 & 108.916 & 12.102 & $70.059^{*}$ \\
\hline & Residual & 21 & 3.627 & 0.173 & \\
\hline & Total & 30 & 112.544 & & \\
\hline
\end{tabular}

* Significant at $\mathrm{p}<0.05$

Oil Yield $\left(R_{1}\right)=$

$$
\begin{gathered}
28.069+1.650 X_{1}+0.737 X_{2}+2.256 X_{3}-1.078 \times 10^{-3} X_{2}^{2} \\
\text { Specific Gravity }\left(R_{2}\right)=0.914-5.057 \times 10^{-3} X_{1} \\
-2.227 \times 10^{-3} X_{2}-6.891 \times 10^{-3} X_{3}+8.122 \times 10^{-5} X_{1} X_{3}
\end{gathered}
$$

Vis $\cos \operatorname{ity}\left(R_{3}\right)$

$$
=40.182-0.551 X_{1}-0.211 X_{3}+0.198 X_{1}^{2}+8.028 \times 10^{-2} X_{1} X_{3}
$$

Free Fatty Acid $\left(R_{4}\right)$

$$
=3.024-0.293 X_{1}-9.090 \times 10^{-2} X_{3}-3.443 \times 10^{-2} X_{1} X_{3}
$$

$$
\begin{aligned}
& \text { Iodine Value }\left(R_{5}\right) \\
& =105.809-0.764 X_{1}-0.416 X_{2}-710 X_{3}-0.129 X_{1}^{2}
\end{aligned}
$$

As shown on equation (11), all the three factors had significant positive linear effect on the oil yield obtained. The temperature of extraction has the highest effect, followed by, the composition of the extraction solvent. This means, the higher the percentage of n-hexane in the solvent, the higher the yield of the Jatropha oil, implying that the non polar solvent will extract more than the polar which agrees with the finding of[19] and[20]. Time of extraction had a negative 
quadratic effect on the yield. All the three factors had negative linear effect on the specific gravity of the oil while the interaction between solvent composition and temperature increases the specific gravity. In addition, solvent composition and temperature of extraction had linear negative effect on the viscosity of the oil whereas the interaction between solvent composition and temperature increases it. Free fatty acid also followed the same trend. Solvent composition had negative quadratic effect on the Iodine value.

\subsection{Optimum surface conditions for Jatropha Oil Extraction}

The models $\left(R_{1}, R_{2}, R_{3}, R_{4}\right.$ and $\left.R_{5}\right)$ were useful for indicating the direction in which to change variables in order to maximize oil yield and minimize specific gravity, viscosity, FFA and Iodine values. The multiple regression equations were solved for the maximum oil yield $(37.3507 \%)$, and minimum specific gravity $(0.8860)$, viscosity $(39.5675 \mathrm{cp})$, FFA $(2.1185 \mathrm{~g} / \mathrm{g})$ and Iodine value (101.5130). The optimum operating condition (coded) predicted for each corresponding response are as shown in Table 6, and are within the experimental range, indicating the validity of the selection of the variables range. The actual values are in the bracket. The response surfaces and contour graphs were obtained by plotting two variables, with the one remaining having the value, which give the optimum.

Table 6. Predicted Optimum Surface conditions for Oil Yield and Properties

\begin{tabular}{cccccc} 
& \multicolumn{5}{c}{ Level of Optimum Response } \\
\cline { 2 - 6 } Factors & Oil Yield & $\begin{array}{c}\text { Specific } \\
\text { gravity }\end{array}$ & Viscosity & FFA & $\begin{array}{c}\text { Iodine } \\
\text { value }\end{array}$ \\
\hline $\mathrm{X}_{1}$ & $2(100)$ & $2(100)$ & 0.9860 & $2(100)$ & $2(100)$ \\
$\mathrm{X}_{2}$ & $2(5)$ & $2(5)$ & $0(3)$ & $0(3)$ & $2(5)$ \\
$\mathrm{X}_{3}$ & $2(60)$ & $2(60)$ & $2(60)$ & $2(60)$ & $2(60)$ \\
\hline
\end{tabular}

Due to earlier mentioned problems associated with Jatropha oil extraction as a feed stock for biodiesel production, a constrained nonlinear programming problem of the form represented in equations (5) to (10) was formulated with each constraint requirement obtained from biodiesel standards (ASTM D 6751-07b and EN 14214-2008 (E) ) as given by[7]. The following standards were imposed on the equations: $\mathrm{b} 2 \leq 0.90, \mathrm{~b} 3 \leq 42, \mathrm{~b} 4 \leq 2.1185$ and $\mathrm{b} 5 \leq 120$ ). This optimization problem was then solved using a nonlinear programme routine of optimization toolbox in Matlab 7.5. The solution obtained is as presented in Table 7. The solution yields a maximum oil yield of $37.3507, \mathrm{R} 2=0.88597, \mathrm{R} 3$ $=39.771, \mathrm{R} 4=2.1185$ and R5 $=101.51$, while the optimum operating conditions were X1 $=2(100), X 2=2(5)$ and X3 $=2(60)$. It then follows that for the best jatropha oil as feedstock for biodiesel production using solvent extraction method, $100 \%$ volume of $n$-hexane should be used at an extraction temperature of $600 \mathrm{C}$ for a maximum extraction time of 5 hours. This condition will not only guarantee maximum oil yield but also meet vital property requirements. When considering other usages of the jathropha oil apart from biodiesel production, such requirements can also be imposed to obtain the best extraction conditions.

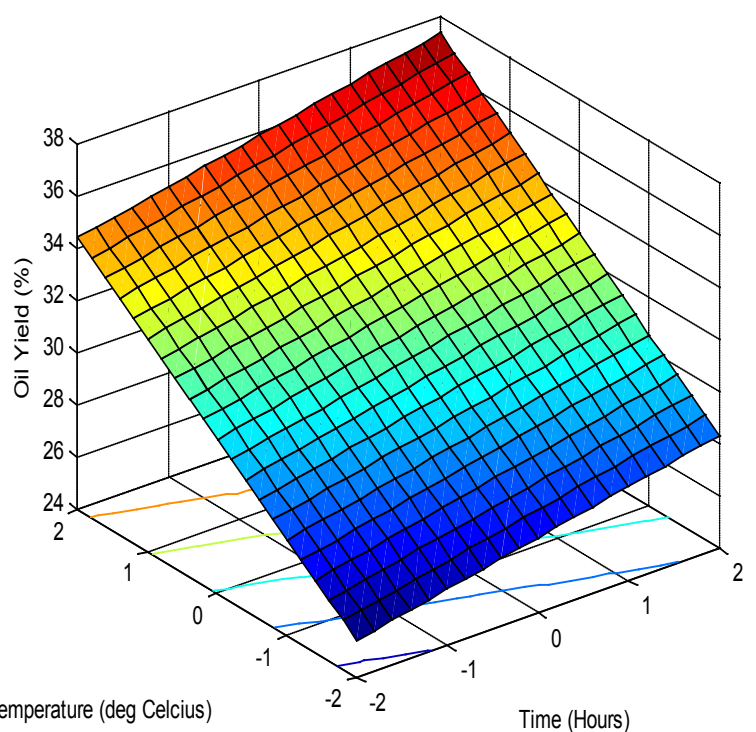

Figure 1. Effect of factors on the Oil Yield

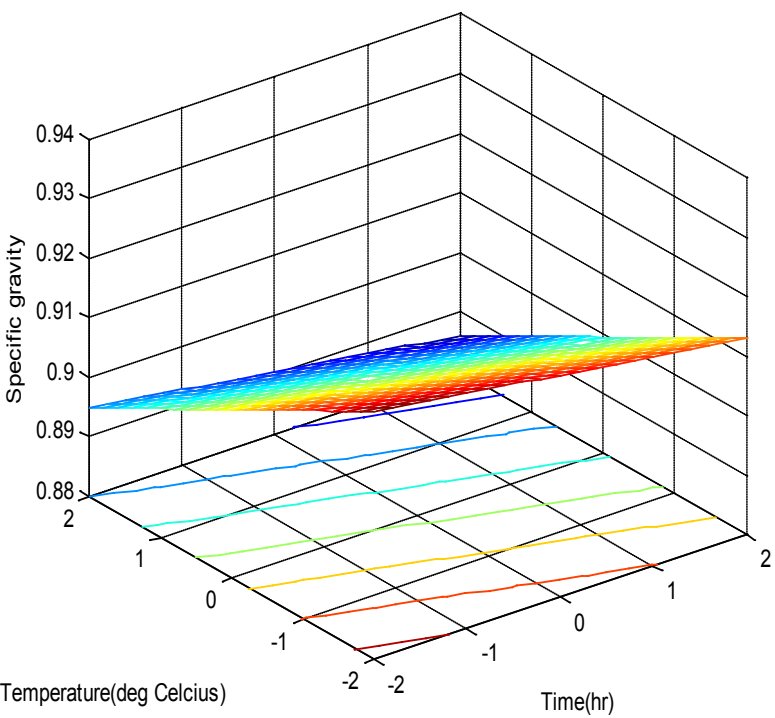

Figure 2. Effect of factors on the Specific gravity

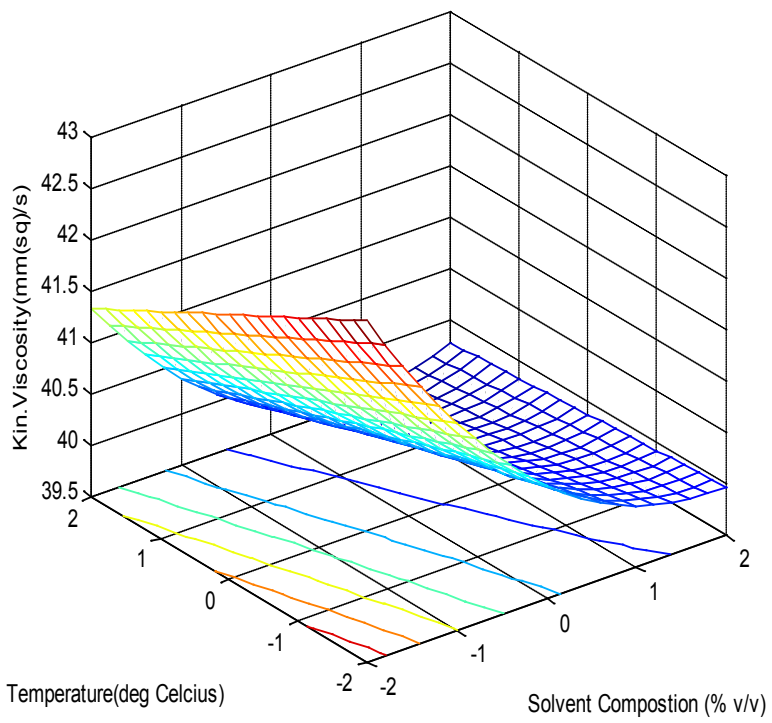

Figure 3. Effect of Factors on the Viscosity 


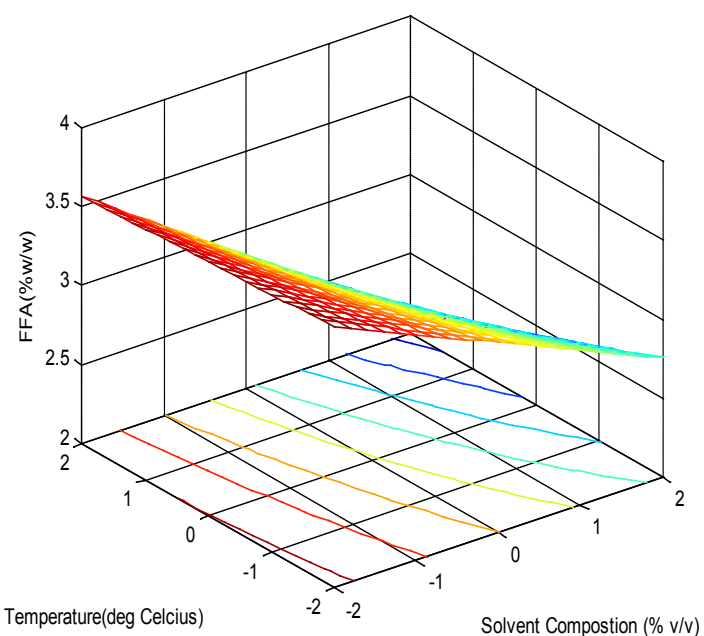

Figure 4. Effect of factors on the FFA

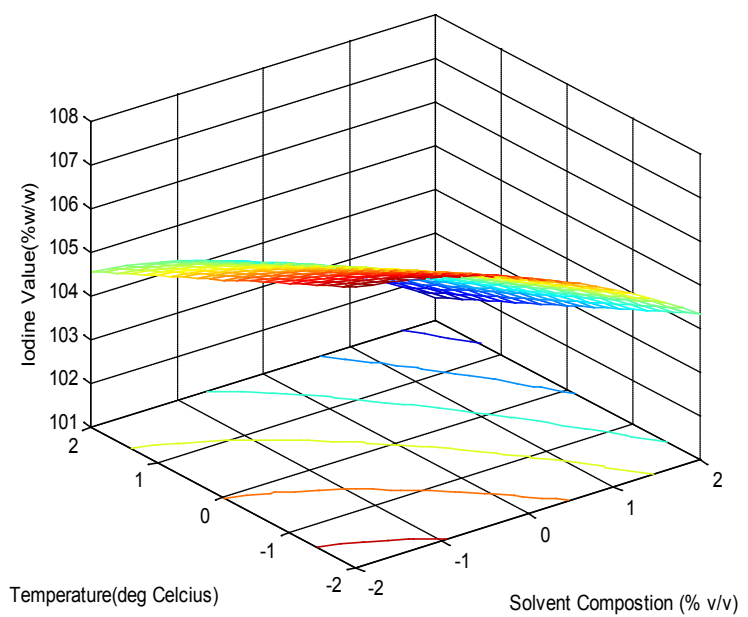

Figure 5. Effect of factors on the Iodine Value

\subsection{Optimum Extraction for Biodiesel Production}

Table 6. Predicted Optimum Conditions for Oil Extraction as Biodesiel Feedstock

\begin{tabular}{cccccc}
\hline Factors & \multicolumn{5}{c}{ Level of Optimum Response } \\
\hline & $\begin{array}{c}\text { Oil } \\
\text { Yield }\end{array}$ & $\begin{array}{c}\text { Specific } \\
\text { gravity }\end{array}$ & Viscosity & FFA & $\begin{array}{c}\text { Iodine } \\
\text { value }\end{array}$ \\
\hline $\mathrm{X}_{1}$ & $2(100)$ & $2(100)$ & $2(100)$ & $2(100)$ & $2(100)$ \\
$\mathrm{X}_{2}$ & $2(5)$ & $2(5)$ & $2(5)$ & $2(5)$ & $2(5)$ \\
$\mathrm{X}_{3}$ & $2(60)$ & $2(60)$ & $2(60)$ & $2(60)$ & $2(60)$ \\
Optimum & 37.3507 & 0.8860 & 39.7710 & 2.1185 & 101.5100 \\
Value & & & &
\end{tabular}

\section{Conclusions}

This study has clearly demonstrated the applicability of nonlinear mathematical programming in selecting extraction conditions for jatropha oil from its seed. This approach has not only resulted in the maximum oil yield through solvent extraction, but has also guaranteed the fulfillment of the requirements for using this oil as a feedstock for biodiesel production. Through this method, $37.35 \%$ oil yield has been achieved with specific gravity 0.8860 , viscosity $39.7710 \mathrm{cp}$, FFA of $2.1185 \%$ and Iodine value of $101.51 \mathrm{~g} / \mathrm{g}$. Such oil obtained from this method will not need expensive pretreatment for biodesel production as compared with other means.

\section{ACKNOWLEDGEMENTS}

The technical support of the technologists at Chemical Engineering Analytical Laboratory, LAUTECH, Ogbomoso is acknowledged

\section{REFERENCES}

[1] M. A. Holl, M. B. Gush, J. Hallowes and D. B. Versfeld (2007). Jatropha curcas in South Africa: an assessment of its water use and bio-physical potential. WRC Report No 1497/1/07. ISBN 978-1-77005-593-3.pg 7.

[2] Ayanbimpe, G. M., Titilayo, H., Ojo, K., Afolabi, E., Opara, F., Orsaah, S. and Ojerinde, O. S., 2009, Evaluation of extracts of Jatropha curcas and Moringa oleifera in culture media for selective inhibition of saprophytic fungal contaminants, Journal of Clinical Laboratory Analysis, 23, $161-164$.

[3] Kumar, A., and Sharma, S., 2008, An evaluation of mulipurpose oil seed crop for industrial uses (Jatropha curcas): A review. Indsutrial Crops and Products. doi:10.1016/j.indcrop. 2008. 01.001

[4] Jongschaap, R. E. E., Corre, W. J., Bindraban, P. S. and Brandenburg, W. A., 2007, Claims and Facts on Jatropha curcas L. Plant Research International B.V. Wageningen. Report 158. pg 16.

[5] Akbar, E., Yaakob, Z., Kamarudin, S. K., Ismail, M. and Salimon, J., 2009, Characteristic and composition of Jatropha Curcas oil seed from Malaysia and its potential as biodiesel feedstock, European Journal of Scientific Research, 29(3),396-403.

[6] Liauw, M. Y., Natan, F. A., Widiyanti, P., Ikasari, D., Indraswati, N. and Soetaredjo, F. E., 2008, Extraction of neem oil (Azadirachta indica A. Juss) using n-hexane and ethanol: studies of oil quality, kinetic and Thermodynamic, ARPN Journal of Engineering and Applied Sciences, 3(3), 49-54.

[7] Nakpong, P. and Wootthikanokkhan,S., 2010, Optimization of biodiesel production from Jatropha curcas L. oil via alkali-catalyzed methanolysis. Journal of Sustainable Energy \& Environment, 1,105-109.

[8] Ramadhas A.S., Jayaraj S. and Muraleedharan C., 2005, Biodiesel production from high FFA rubber seed oil, Fuel, 84,335-340.

[9] De Oliveira J. S., Leite, P.M., De Souza, L. B., Mello, V. M., Silva, E. C., Rubim, J. C., Meneghetti, S. M. P. and Suarez, P. A. Z., 2009, Characteristics and composition of Jatropha gossypiifolia and Jatropha curcas L. oils and application for biodiesel production, Biomass Bioenergy, 33(2),449-453.

[10] Twari K.A., Kumar A., and Raheman H., 2007, Biodiesel production from jatropha oil (jatropha curcas) with high free fatty acids: an optimization process. Biomass and Bioenergy, 


$$
31(8), 569-575
$$

[11] Sayyar S., Abidin Z. Z., Yunus R and Muhammad A., 2009, Extraction of oil from jatropha seeds - optimization and kinetics, American journal of Applied Sciences, 6(7),13901395.

[12] Vyas A.P., Subrahmanyam N., and Patel P.A., 2009, Production of biodiesel through transesterification of Jaatropha oil using $\mathrm{KNO}_{3} / \mathrm{Al}_{2} \mathrm{O}_{3}$ solid catalyst. Fuel, 88,625 - 628 .

[13] Devappa R.K., Makkar H.P.S., and Becker K., 2010, Optimization of conditions for the extraction of phorbol esters from Jatropha oil, Biomass and Bioenergy, 34(8),1125 1133.

[14] Berchmans, H. J. and Hirata S., 2008, Biodiesel production from crude Jatropha curcas L. seed oil with a high content of free fatty acids, Bioresources Technology, 99(6),1716-1721.

[15] Patil P.D. and Deng, S.,2009, Optimization of biodiesel production from edible and non-edible vegetable oils, Fuel, 88,1302-1306.

[16] Deng X., Fang Z. and Liu Y., 2010, Ultrasonic transesterification of Jatropha curcas oil to biodiesel by a two - step process. Energy Conversion and Management, 51, $2802-$ 2807.

[17] Hawash S., Kamal N., Zather F., Kenawi D., and Diwani G.B., 2009, Biodiesel fuel from Jatropha oil via non - catalytic supercritical methanol transesterification, Fuel, 88,579 -582.
[18] Ghadge S. V and Raheman H.,2005, Biodiesel production from mahua ( Madhuca indica) oil having high free fatty acids, Biomass and Bioenergy, 28(6),601 -605.

[19] Shah,S., Sharma A and Gupta, M. N.,2004, Extraction of Oil from Jatropha Curcas L seed kernels by enzyme assisted three phase partitioning, Industrial Crops and Products, 20, $275-279$.

[20] Shah,S., Sharma A and Gupta, M. N.,2005, Extraction of Oil from Jatropha Curcas L seed kernels by combination of ultrasonication and aqueous enzymatic oil extraction. Bioresource Technology . 96,121 -123.

[21] Achten W. M. J., Verchot, L., Franken, Y. J., Mathijs, E., Singh, V. P., Aerts, R. and Muys, B., 2008, Jatropha biodiesel production and use (a literature review). Biomass and bioenergy, 32(12), 1063-1084.

[22] Ghadge S. V and Raheman H.,2006,Process optimization for biodiesel production from mahua (Madhuca indica) oil using surface response methodology, .Bioresource Technology, 97(3),379-384.

[23] Karunakaran, V.V.,2006, Quality assurance and optimization studies of light weight polyurethane prosthetic foot. Trends Biomaterials. Artificial. Organs, 19(2),63-69.

[24] Jouhaud, J.C., Sagaut, P., Montagnac, M., and Laurenceau, J.,2007, A surrogate model based multi-disciplinary shape optimization method with application to a 2D subsonic airfoil. Computers and Fluids 36(3),520-529. 